\title{
EFFECT OF AMMONIUM AS NITROGEN SOURCE ON PRODUCTION OF $\delta$-(L- $\alpha$-AMINOADIPLY)-L-CYSTEINYL-D-VALINE SYNTHETASE BY CEPHALOSPORIUM ACREMONIUM C-10
}

\author{
Jinyou Zhang ${ }^{\dagger}$, SAul Wolfi ${ }^{\dagger \dagger}$ and Arnold L. Demain \\ Fermentation Microbiology Laboratory, \\ Department of Applied Biological Sciences, \\ Massachusetts Institute of Technology, \\ Cambridge, Massachusetts 02139, U.S.A. \\ ${ }^{\dagger}$ Department of Chemistry, Queens University, \\ Kingston, Ontario, Canada K7L 3N6
}

(Received for publication June 13, 1987)

\begin{abstract}
Cephalosporin production by Cephalosporium acremonium strain C-10 was suppressed when the organic nitrogen source $\left(1.2 \% \mathrm{~L}\right.$-asparagine) was replaced by $1.2 \%\left(\mathrm{NH}_{4}\right)_{2} \mathrm{SO}_{4}$. A higher level of $\left(\mathrm{NH}_{4}\right)_{2} \mathrm{SO}_{4}(3.5 \%)$ led to even greater suppression. Ammonium repression was exerted on formation of $\delta$-(L- $\alpha$-aminoadipyl)-L-cysteinyl-D-valine (ACV) synthetase, together with that of expandase; a lesser effect by ammonium was observed on cyclase production. Inhibition of ACV synthetase activity byammonium was also observed ( $\mathrm{ca} .50 \%$ inhibition at $250 \mathrm{mM} \mathrm{NH}_{4}{ }^{+}$).
\end{abstract}

Nitrogen sources which are readily assimilated for growth often interfere with secondary metabolism ${ }^{1 \sim 3)}$. Such control has been shown to be important in organisms producing $\beta$-lactam antibiotics, i.e., Streptomyces clavuligerus $\left.{ }^{3}, 4\right)$, Nocardia lactamdurans ${ }^{51}$, Cephalosporium acremonium ${ }^{6)}$ and Penicillium chrysogenum ${ }^{7)}$.

In C. acremonium strain CW-19, ammonium appeared to interfere primarily with production of the cephalosporins rather than that of the intermediate, penicillin $\mathrm{N}^{\text {()) }}$. It was found that ammonium repressed the formation of deacetoxycephalosporin C synthetase ("expandase") but had only a slight affect on isopenicillin $\mathrm{N}$ synthetase ("cyclase") formation. However, higher concentrations of ammonium shut off penicillin $\mathrm{N}$ production, indicating additional negative control of an early enzyme of the pathway.

We recently developed a cell-free system for detecting $\delta$-(L- $\alpha$-aminoadipyl)-L-cysteinyl-D-valine synthetase ("ACV synthetase") activity ${ }^{8)}$. The present paper describes the effect of ammonium on the formation of this initial enzyme of the cephalosporin biosynthetic pathway as well as expandase and cyclase. For this study, we have used the high producing strain, C. acremonium $\mathrm{C}-10^{9}$.

\section{Materials and Methods}

\section{Organisms}

C. acremonium C-10 (Acremonium chrysogenum ATCC 48272) was used throughout the study. Assay organisms were Micrococcus luteus ATCC 381 for cyclase and Escherichia coli ESS for expandase.

Medium and Culture Conditions

Slant medium, seed medium (No. 1) and chemically-defined medium were as previously described ${ }^{10)}$, using the same culture conditions except that $1.5 \mathrm{~g}$ oleic acid per liter was added to the chemically-defined medium and the inoculum level was $8 \%$. When required, $1.2 \%$ or $3.5 \%\left(\mathrm{NH}_{4}\right)_{2} \mathrm{SO}_{4}$

+ Permanent address: Sichuan Industrial Institute of Antibiotics, Chengdu, Sichuan, People's Republic of China. 
(182 or $530 \mathrm{mM} \mathrm{NH}_{4}{ }^{+}$, respectively) was added to replace the $1.2 \% \mathrm{~L}$-asparagine $(182 \mathrm{~mm} \mathrm{~N}$ ) as major nitrogen source.

\section{Fermentation Parameters}

Growth: Growth was measured by absorbance using the Klett Summerson colorimeter with a red filter. A cell dry weight of $1 \mathrm{mg} / \mathrm{ml}$ was found equivalent to $180 \mathrm{Klett}$ units. The broths were diluted 40 -fold before measurements were made; absorbance was linearly related to dry cell weight when the former was below 150 Klett units.

Protein Concentration: Protein in cell-free extracts was measured by the method of BRADFORD ${ }^{11}$. Bovine serum albumin was used as standard.

$\beta$-Lactam Antibiotics: Production of $\beta$-lactam antibiotics during fermentations was measured by the chemical assay of LüBBE et al. ${ }^{22)}$ using cephalosporin $C$ as standard. Strain $C-10$ produces predominantly cephalosporin $C$ and lesser amounts of deacetoxycephalosporin $C$ and penicillin $\mathbf{N}^{10,12)}$.

\section{Preparation of Cell-free Extracts and Enzyme Assays}

The cells were broken with a French Press in the presence of glycerol, as reported earlier ${ }^{13}$. After desalting the crude cell-free extracts, cyclase and expandase assays were carried out as described before ${ }^{14}$, using authentic isopenicillin $\mathrm{N}$ and cephalosporin $\mathrm{C}$ as standards, respectively. One unit of enzyme activity is that which produces $1 \mu \mathrm{g}$ of isopenicillin $\mathrm{N}$ or cephalosporin $\mathrm{C}$ equivalent per minute, respectively. ACV synthetase activity was measured by estimating the amounts of ACV produced in the cell-free reaction, using the previously reported HPLC method ${ }^{8,13}$. One unit of ACV synthetase activity produces $1 \mathrm{pmol}$ of ACV per minute.

\section{Results}

\section{Comparison of $\left(\mathrm{NH}_{4}\right)_{2} \mathrm{SO}_{4}$ and L-Asparagine as Nitrogen Sources}

It is generally recognized that organic nitrogen sources are superior to ammonium salts for $\beta$ lactam production. For C. acremonium, L-asparagine is the amino acid of choice ${ }^{\theta}$. Fig. 1 shows that L-asparagine supported higher growth and higher volumetric production of $\beta$-lactams than did $\left(\mathrm{NH}_{4}\right)_{2} \mathrm{SO}_{4} \cdot \quad 1.2 \%\left(\mathrm{NH}_{4}\right)_{2} \mathrm{SO}_{4}$ exerted repression on $\mathrm{ACV}$ synthetase, along with the expected repression of expandase and a lesser effect on cyclase ${ }^{\mathrm{B})}$.

\section{Effect of Ammonium at an Increased Concentration}

In Fig. 1, it can be seen that the pH dropped considerably (down to 5.2 5.4) in the fermentation with ammonium sulfate but remained rather stable with asparagine. Furthermore, the cells presumably used asparagine as a carbon source as well as a nitrogen source for growth, thus achieving a higher cell density; no marked effect on specific production of antibiotics by L-asparagine was observed. In order to study ammonium repression in the absence of an additional carbon source, and to rule out the possibility that the $\mathrm{pH}$ difference causes the difference in synthetase activities, fermentations with normal $(1.2 \%)$ and excess (3.5\%) concentrations of $\left(\mathrm{NH}_{4}\right)_{2} \mathrm{SO}_{4}$ were compared (Fig. 2). Growth and $\mathrm{pH}$ changes were similar in the two fermentations, and there was suppression of antibiotic synthesis on both volumetric and specific bases by the higher concentration of ammonium. The results confirmed the repression of both expandase and ACV synthetase by $\mathrm{NH}_{4}{ }^{+}$. Again the effect on cyclase was less pronounced.

\section{Effect of Ammonium on ACV Synthetase Activity}

Since the initial enzyme of biosynthetic pathways is often subject to inhibition of enzyme activity, we tested whether $\mathrm{NH}_{4}{ }^{+}$could inhibit ACV synthetase activity. As shown in Table 1, ammonium exerts $50 \%$ inhibition at about $250 \mathrm{~mm}\left(1.7 \%\left(\mathrm{NH}_{4}\right)_{2} \mathrm{SO}_{4}\right)$. Similar effects were observed with $\mathrm{NH}_{4} \mathrm{Cl}$ 
Fig. 1. Effect of $1.2 \%\left(\mathrm{NH}_{4}\right)_{2} \mathrm{SO}_{4}(\square)$ and $1.2 \% \mathrm{~L}$-asparagine (1) on growth, pH and formation of $\beta$ lactam antibiotics and cephalosporin synthetases by Cephalosporium acremonium $\mathrm{C}-10$.

DCW: Dry cell weight.
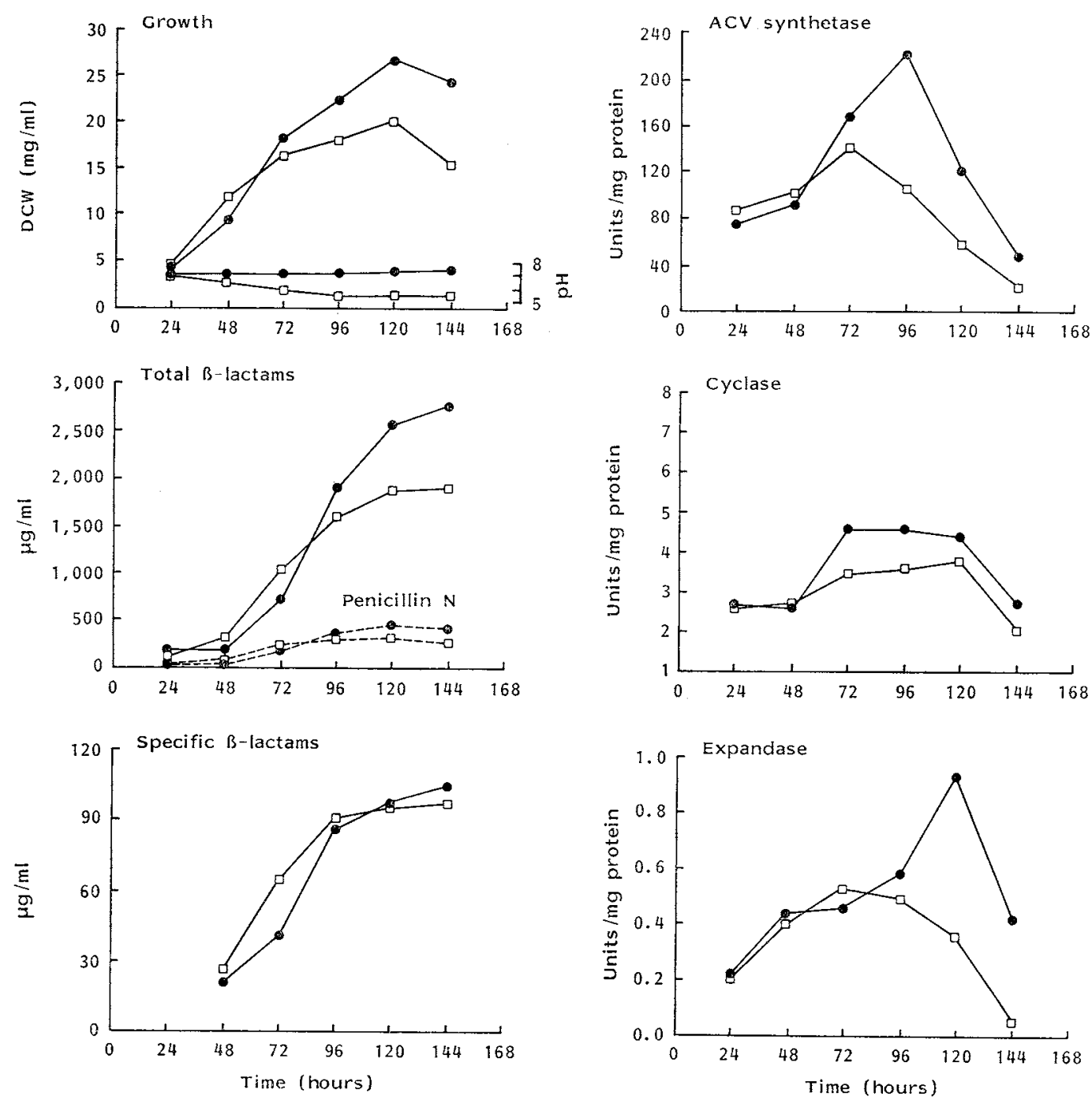

(data not shown). CASTRO et al.5) found no inhibition of cyclase, epimerase and expandase by up to $40 \mathrm{~mm}$ ammonium in $N$. lactamdurans.

\section{Discussion}

ACV synthetase, the first enzyme of the $\beta$-lactam biosynthetic pathway, is crucial to both penicillin and cephalosporin biosynthesis. We recently reported that in $C$. acremonium this enzyme is subject to methionine induction ${ }^{15}$, leading to an increase in $\beta$-lactam production. The data presented in this paper indicate that this enzyme is also the target of ammonium repression, and thus explains the observation that penicillin $\mathrm{N}$ production in C. acremonium is suppressed by high levels of ammonium ${ }^{6}$. Repression of both expandase and $\mathrm{ACV}$ synthetase by $\mathrm{NH}_{4}{ }^{+}$contributes to a decrease in cephalosporin production. We have also observed inhibition of $\mathrm{ACV}$ synthetase by ammonium which could also contribute to the interference with $\beta$-lactam formation. 
Fig. 2. Effect of $1.2 \%\left(\mathrm{NH}_{4}\right)_{2} \mathrm{SO}_{4}(0)$ and $3.5 \%\left(\mathrm{NH}_{4}\right)_{2} \mathrm{SO}_{4}(\square)$ on growth and formation of $\beta$-lactam antibiotics and cephalosporin synthetases by Cephalosporium acremonium $\mathrm{C}-10$.
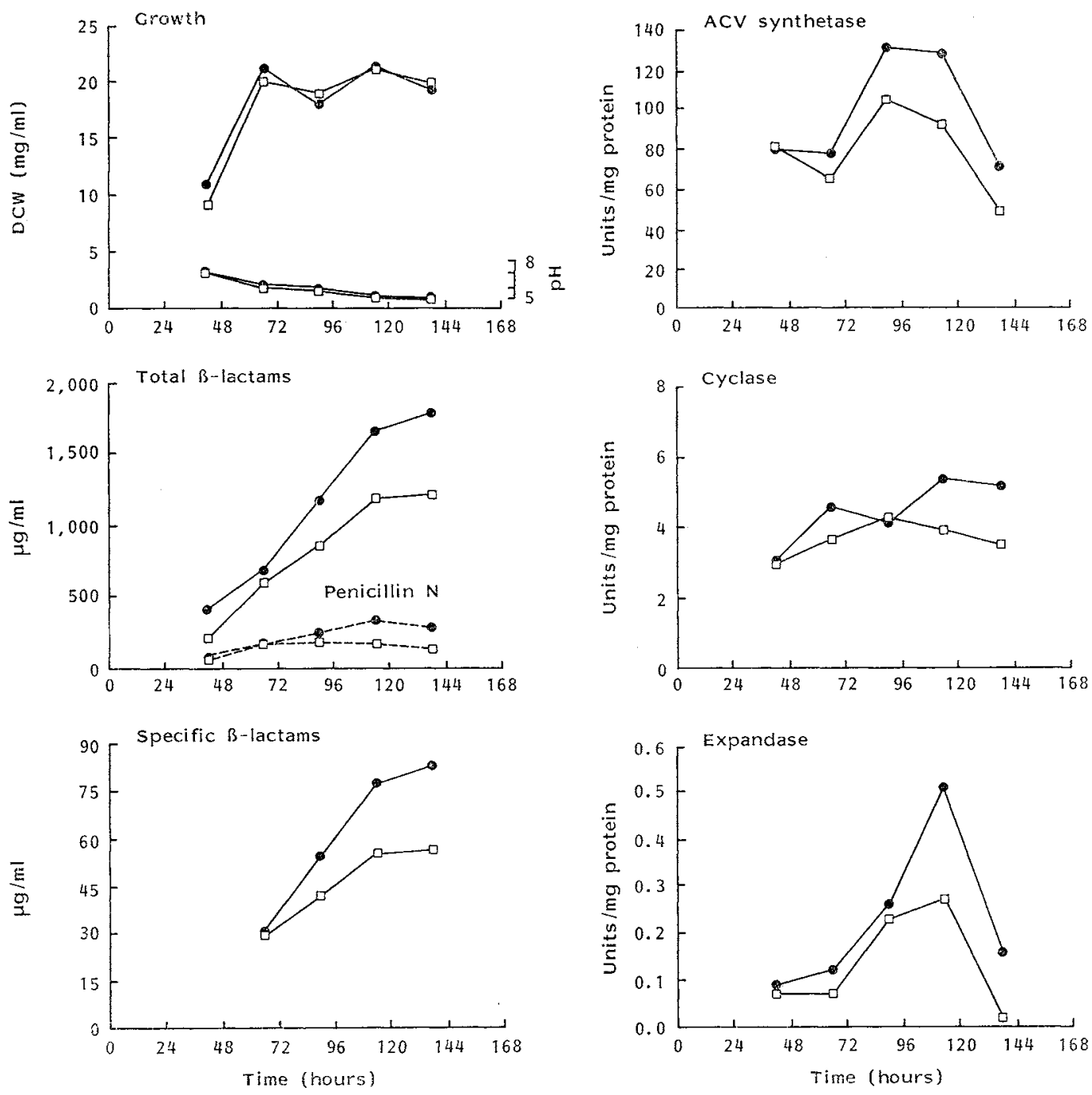

Table 1. Effect of $\mathrm{NH}_{4}{ }^{+}$on $\mathrm{ACV}$ synthetase activity ${ }^{\mathrm{a}}$.

\begin{tabular}{lrrrrrrrrr}
\hline$\left(\mathrm{NH}_{4}\right)_{2} \mathrm{SO}_{4}(\%)$ & 0 & 0.08 & 0.17 & 0.33 & 0.66 & 0.99 & 1.32 & 1.98 & 2.64 \\
\hline $\mathrm{NH}_{4}{ }^{+}(\mathrm{mM})$ & 0 & 12.5 & 25 & 50 & 100 & 150 & 200 & 300 & 400 \\
\hline Activity $(\%)$ & 100 & 99.3 & 91.1 & 76.4 & 72.3 & 63.1 & 55.4 & 42.8 & 36.2 \\
\hline
\end{tabular}

a $\mathrm{NH}_{4} \mathrm{Cl}$ showed a similar degree of inhibition on a molar basis.

We previously reported that strain C-10 (the high producing strain which was derived from the low producing strain $\mathrm{CW}-19$ ) was somewhat derepressed in glucose control when compared to $\mathrm{CW}$ 19. Here we find that $\mathrm{C}-10$ is still sensitive to ammonium repression and we might expect that screening or selecting for ammonium repression-resistant mutants could provide improved antibiotic producers.

Regulation in other $\beta$-lactam producers shows different patterns from that observed in $C$. acremonium. BRAÑ et al. ${ }^{16)}$ compared three enzymes in $S$. clavuligerus and found cyclase to be the most sensitive, expandase moderately sensitive and epimerase inert to $\mathrm{NH}_{4}{ }^{+}$repression. CASTRO et al. ${ }^{5)}$ 
found cyclase, epimerase and expandase to be coordinately repressed in N. lactamdurans. Although they did not test the effect on ACV synthetase directly, they did report that in vivo intracellular accumulation of $\mathrm{ACV}$ was decreased by growth in a high concentration of ammonium.

\section{Acknowledgments}

The work at Massachusetts Institute of Technology was supported by the National Science Foundation. The Queens University activities were funded by the Natural Science and Engineering Research Council of Canada. J.-Y. ZHANG acknowledges support from the Educational Committee of the People's Republic of China. We thank D. Liberman, M. JeRmini and N. A. Solomon for encouragement and advice.

\section{References}

1) Aharonowitz, Y.: Regulatory interrelationships of nitrogen metabolism and cephalosporin biosynthesis. In Genetics of Industrial Microorganisms. Eds., O. K. SEBEK \& A. I. LASKIN, pp. 210 217, Amer. Soc. Microb., Washington, D.C., 1979

2) ŌMURA, S.; Y. TANÀAa, H. Mamada \& R. MAsUma: Effect of ammonium ion, inorganic phosphate and amino acids on the biosynthesis of protylonolide, a precursor of tylosin aglycone. J. Antibiotics 37 : 494 502, 1984

3) Aharonowitz, Y. \& A. L. Demain: Nitrogen nutrition and regulation of cephalosporin production in Streptomyces clavuligerus. Can. J. Microbiol. 25: 61 67, 1979

4) Demain, A. L. \& A. F. BRaÑa: Control of cephamycin formation in Streptomyces clavuligerus by nitrogenous compounds. In Regulation of Secondary Metabolite Formation. Ed., H. KLEINKAUf et al., pp. 77 88, VCH Verlagsgesellschaft $\mathrm{mbH}$, Weinheim, 1985

5) Castro, J. M.; P. Liras, J. Cortes \& J. F. Martin: Regulation of $\alpha$-aminoadipyl-cysteinyl-valine, isopenicillin $\mathrm{N}$ synthetase, isopenicillin $\mathrm{N}$ isomerase and deacetoxycephalosporin $\mathrm{C}$ synthetase by nitrogen sources in Streptomyces lactamdurans. Appl. Microbiol. Biotechnol. 22: 32 40, 1985

6) Shen, Y.-Q.; J. Heim, N. A. Solomon, S. Wolfe \& A. L. Demain: Repression of $\beta$-lactam production in Cephalosporium acremonium by nitrogen sources. J. Antibiotics 37: 503 511, 1984

7) Sanchez, S.; L. Pantagua, R. C. Mateos, F. Lara \& J. More: Nitrogen regulation of penicillin G biosynthesis in Penicillium chrysogenum. In Advances in Biotechnology. Vol. III. Fermentation Products. Eds., C. VézinA \& K. Singh, pp. 147 154, Pergamon Press, Toronto, 1979

8) Banko, G.; A. L. Demarn \& S. Wolfe: $\delta$-(L- $\alpha$-aminoadipyl)-L-cysteinyl-D-valine synthetase: A multifunctional enzyme with broad substrate specificity for synthesis of penicillin and cephalosporin precursors. J. Am. Chem. Soc. 109: 2858 2860, 1987

9) Demain, A. L.: Strain exchange between industry and academia. ASM News 49: 431, 1983

10) Shen, Y.-Q.; S. Wolfe \& A. L. Demain: Levels of isopenicillin $N$ synthetase and deacetoxycephalosporin C synthetase in Cephalosporium acremonium producing high and low levels of cephalosporin C. Bio/ Technology 4: $61 \sim 63,1986$

11) BRADFORD, M. M.: A rapid and sensitive method for the quantification of microgram quantities of protein using the principle of protein dye binding. Anal. Biochem. 12:248 254, 1976

12) LÜBBE, C.; Y.-Q. SHEN \& A. L. DemAIN: A simple and rapid chemical method for the determination of cephalosporins. Appl. Biochem. Biotechnol. 12: $31 \sim 35,1986$

13) Banko, G.; S. Wolfe \& A. L. Demain: Cell-free synthesis of $\delta$-(L- $\alpha$-aminoadipyl)-L-cysteine, the first intermediate of penicillin and cephalosporin biosynthesis. Biochem. Biophys. Res. Commun. 137: 528 535,1986

14) Kupka, J.; Y.-Q. Shen, S. Wolfe \& A. L. Demain: Studies on the ring-cyclization and ring-expansion enzymes of $\beta$-lactam biosynthesis in Cephalosporium acremonium. Can. J. Microbiol. 29: 488 496, 1983

15) Zhang, J.-Y.; G. Banko, S. Wolfe \& A. L. Demain: Methionine induction of ACV synthetase in Cephalosporium acremonium. J. Ind. Microbiol. 2: 251 225, 1987

16) Braña, A. F.; S. Wolfe \& A. L. Demarn: Ammonium repression of cephalosporin production by Streptomyces clavuligerus. Can J. Microbiol. 31: 736 743, 1985 